\title{
Assessment of Newly Released and Well-Established Rabbiteye Blueberry (Vaccinium ashei Reade) Cultivars in North Alabama
}

\author{
Richard Joel Potter, Elina D. Coneva \\ 101 Funchess Hall, Department of Horticulture, Auburn University, Auburn, AL, USA \\ Email: edc0001@auburn.edu
}

How to cite this paper: Potter, R.J. and Coneva, E.D. (2018) Assessment of Newly Released and Well-Established Rabbiteye Blueberry (Vaccinium ashei Reade) Cultivars in North Alabama. Agricultural Sciences, 9, 78-98.

https://doi.org/10.4236/as.2018.91007

Received: November 22, 2017

Accepted: January 16, 2018

Published: January 19, 2018

Copyright (ㅇ 2018 by authors and Scientific Research Publishing Inc. This work is licensed under the Creative Commons Attribution International License (CC BY 4.0).

http://creativecommons.org/licenses/by/4.0/

\section{(c) (i) Open Access}

\begin{abstract}
Many cultivars of rabbiteye blueberry (Vaccinium ashei Reade) have been recently developed with diverse vegetative and cropping characteristics, but scientific data on their performance in Alabama is limited. An experiment was established at the North Alabama Horticulture Research Center, Cullman, AL (lat. $34^{\circ} 11^{\prime} \mathrm{N}$, long. $-86^{\circ} 47^{\prime} \mathrm{E}$ ), USDA Hardiness Zone $7 \mathrm{~B}$, to evaluate the performance and horticultural value of the following rabbiteye blueberry cultivars: "Alapaha", "Baldwin", "Brightwell", "Climax", "Ira", "Montgomery", "Onslow", "Powderblue", "Premier", "Tifblue", and "Yadkin". Cultivar flowering and ripening season, yield potential, fruit quality characteristics, and vegetative growth were investigated during 2009 and 2010. "Alapaha", "Climax", and "Premier" were found to have early ripening in north Alabama. "Alapaha" flowered later than the earliest flowering cultivars, but ripened consistently early, and this later flowering can serve to protect "Alapaha" crop from late freeze damage. Cultivars were not found to differ with respect to their cumulative yield in their fifth and sixth leaf. "Brightwell" and "Climax" had the firmest berries, while "Climax" and "Premier" had the sweetest berries.
\end{abstract}

\section{Keywords}

Rabbiteye Blueberry, Fruit Quality, Yield, Cold Tolerance

\section{Introduction}

Rabbiteye blueberries (Vaccinium ashei Reade) are the most prominent and 
the best adapted of the blueberry varieties for cultivation in the southeastern United States. Alabama, Louisiana, Mississippi, South Carolina, and Texas grow rabbiteye blueberry almost exclusively [1] [2]. Rabbiteye blueberries are native to the Southeast, tolerant to heat and droughts, more resistant to diseases and insects, grow on a wide range of soils, provide abundant yields, sweet fruit with excellent firmness, and a longer shelf life than other blueberry species [3] [4]. Rabbiteye blueberry bushes can grow to a height of 10 feet or more, have high vigor, and produce small to medium-large berries ranging from black to light blue [5]. Commercial rabbiteye yields typically range from 2,270 to $3,630 \mathrm{~kg} /$ acre on well-maintained fields, sometimes reaching as high as $4,535 \mathrm{~kg} / \mathrm{acre}$, and a blueberry orchard can continue to be productive for 30 years or more [4].

Rabbiteye blueberries are historically an important commercial crop for Alabama, and many farms produce rabbiteye blueberries for sale in the fresh market either exclusively, or as a supplemental crop [6]. The USDA ESMIS reports that in 2012 Alabama ranked 13 in the nation by farm-gate value of blueberry production [7]. Essentially $100 \%$ of the blueberries currently produced in Alabama are sold in the fresh market [8]. In Alabama, 310 acres were harvested in 1998, yielding $730 \mathrm{~kg} / \mathrm{acre}$. According to the National Agricultural Statistics Service [8], over the next decade, there was only a $3 \%$ increase in harvested acreage, but a $71 \%$ increase in yield per acre in Alabama. The blueberry acreage almost doubled by 2009, when an additional 275 acres were established in the Dothan area alone (Clint Smith, president of the Wiregrass Blueberry Growers Association, personal communication). Alabama farm gate value for blueberries has increased in the same time period by approximately 13\% [8].

Public interest has likely aided this increase in demand and production due to the increased reports of the fruit's health benefits [9] [10]. Blueberries contain vitamins $\mathrm{A}, \mathrm{C}$, and $\mathrm{E}$, as well as carbohydrates, protein, fiber, and fat, and also contain organic acids and polyphenolic substances including chlorogenic, citric, malic, quinic, acetic, caffeic, p-coumaric, and shikimic acids [9]. According to Druice and Percival [9], the combinations of these organic compounds give blueberries the highest oxygen radical absorbency capacity of over forty commercially available fruits and vegetables. The nutraceutical compounds in blueberries have been linked to a number of health benefits, such their capability to reduce blood sugar, serum cholesterol, and triglyceride levels. Blueberries also have antiallergenic, anti-viral and antiproliferative activities [9], and they have been found to have a protective effect against diabetes, stroke, lung and stomach cancers. Additional health benefits of blueberries are their effect on reducing the loss of age-related motor skills and memory, and improving urinary tract and visual health [9] [10].

Cultivation of rabbiteye blueberries began in 1940 with a cooperative effort between the U.S. Department of Agriculture, the University of Georgia, and North Carolina State University [1] [2]. Superior selections from the wild were 
intercrossed, and thorough seedling screening was performed [11]. The first cultivars were released in 1950 [11], but the planting of cultivated blueberries was initially slow in North America [11]. Early cultivars tended to have fruit that were nearly black, with a poor taste, and large seeds, but have since been replaced by improved varieties [5].

A narrow gene pool plagues rabbiteye breeding, as nearly all of the nuclear genes originate from four selections: "Myers", "Black Giant", "Ethel", and "Clara" [12]. Inbreeding has been used to promote desirable traits, but has resulted in the loss of vigor and fruit weight [12]. In addition, narrower germplasms increase the risk of reduced pest/disease resistance, and efforts are currently being made in breeding programs to widen the germplasm of Vaccinium species but increased efforts are needed [12].

Currently, Florida, Georgia, Texas, North Carolina, and Mississippi all have active rabbiteye blueberry breeding programs aimed largely at producing early ripening, low hilling, high yielding cultivars [1]. Some of the other qualities that are desired in new rabbiteye blueberry cultivars are the development of increased cold hardiness, better adaptation to particular climates, adaptation to mineral soils or soils with high $\mathrm{pH}$, the extension of the fruiting season, high vigor, reduced plant stature, high quality fruit, suitability for mechanical harvest, disease and insect resistance, tolerance to environmental stress, and higher nutraceutical properties [2] [11] [12].

Yield is the most important trait from the grower's perspective, and cultivars that are not only high yielding, but are consistently high yielding across years are desirable [13]. Yield is a function of many factors including the amount of flower clusters per plant, flower number per cluster, flowering twigs per bush, fruit set and drop, and fruit size [14]. The commercial crop yields are typically considerably less than that documented in experimental plots, primarily due to inconsistencies in plant health and pollination as well as seasonal influences [15].

Flowering and fruiting seasons are important traits that vary from cultivar to cultivar. Late flowering, early ripening cultivars and/or tolerance to low temperatures during and following bloom are also desirable traits that breeders are striving for in rabbiteye due to the risk of late spring frost damage [12] [16] [17]. In much of Alabama, blueberries with low chilling requirements are used, but once the chilling requirements are met, there is still a risk of a damaging late spring frost [17]. With the availability of cultivars with a range of flowering times, a grower can select cultivars that match their risk of late spring frosts and consequent crop loss [13]. Rabbiteye blueberry floral buds tend to be rather cold hardy, but as flower development continues, the bud's susceptibility to cold damage increases [17].

Spiers [17], documented 7 distinct stages of floral bud development. An inverse relationship was observed between the stage of development and the flower bud's susceptibility to cold damage [17]. Spiers [17] also found that swollen 
flower buds were not damaged by temperatures of $-4^{\circ} \mathrm{C}$, but some were killed at $-6^{\circ} \mathrm{C}$. At stage four, or when individual flowers become distinguishable, flower buds were killed by $-4^{\circ} \mathrm{C}$, and during the transition to the distinctly separated individual flowers stage, temperatures of $-2^{\circ} \mathrm{C}$ were lethal. Temperatures of $0^{\circ} \mathrm{C}$ were not found to damage any of the flower buds in developmental stages one through five, but temperatures of $-1^{\circ} \mathrm{C}$ were damaging to flowers with open corollas approaching stage six of flower bud development.

In addition to the flowering period, the ripening period is also important in blueberry production. The ability to target an early market for premium prices is one reason a grower would risk a late freeze by planting an early flowering and fruiting cultivar such as "Climax" [13]. Cultivars can be combined with early, mid, and late season ripening to extend the harvest season over 6 to 8 weeks [13].

The intended method of harvest also affects cultivar selection, such as mechanical harvesting or hand harvesting [12]. For mechanical harvesting, plants should exhibit concentrated ripening periods, moderate vigor, a moderate number of narrowly upright canes (which could be trained into a narrow hedge row to fit a mechanical harvester), a large number of flower buds and canes, a high resistance to wound pathogens, small to moderate fruit size, a light blue color, small scars, loose fruit clusters, moderate ease of fruit removal, crisp flesh texture, a firm berry, tough/elastic skin, and desirable sugar/acid ratio to assure extended shelf life [12]. According to NeSmith et al. [18], "Climax" is considered the standard in Georgia for mechanically harvested blueberries for the fresh market. It has an upright form, narrow crown, and a concentrated harvest [19] [20]. When compared to blueberry crops harvested by commercial hand-pickers, Van Dalfsen [21] found mechanical harvesters had a reduction in yield of 14 to $16 \%$, and roughly ten times as many immature berries.

Historically, high yield and firmness to withstand shipping were the primary characteristics selected for, but over the past two decades fresh blueberry consumption has increased, leading to emphasis on other qualities such as berry size, increased shelf life, and increased berry quality [22]. Fresh blueberries are being shipped longer distances as blueberry gains popularity, causing an increase in demand for fruit that are of high quality, reduced softening, and increased shelf life [23]. Marketing of rabbiteyes in the southern states ranges from $90 \%$ local sales in South Carolina to 95\% shipping in Georgia [1]. Berry size and quality are extremely important for fresh market blueberries, and firm varieties are well-suited for long-distance shipping [5] [13] [22]. Crops grown for farmers' markets need to be of very high quality, but firmness for shipping is not as much of a concern [22] [24] [25].

Firmness is one of the key factors analyzed for cultivar selection [5], and rabbiteye blueberries are more firm than those of northern highbush ( $V$. corymbosum) or the evergreen blueberry ( $V$. darrowii) [26]. Cultivars with softer berries will often bruise if they are harvested mechanically and do not withstand ship- 
ping well [27]. Firm berries are well-suited for mechanical harvesting and long-distance shipping [5] [22] [25]. Machine harvested berries have been found to be softer and show a higher incidence of postharvest decay than hand harvested berries due to damage from the machine harvester [27]. As farms and farm cooperatives continue to grow in size with large plantings and shipping distances increase, firmer rabbiteye fruits will be needed for mechanical harvesting and shipping [27]. Marshall et al. [25] showed that when breeding efforts are aimed at producing firmer fruits, cultivars may be selected that are susceptible to rain induced cracking, as firmer varieties tend to have more susceptibility to cracking. Cultivars should be screened for both firmness and susceptibility to cracking [25].

The quality of fresh fruit is usually indicated by four major aspects: visual quality (color, and the lack of skin disorders); organoleptic quality (taste, texture, and flavor); nutritional quality and hygienic quality (microbiological safety, residues) [26]. Fruit size is among the most important traits for the fresh blueberry market, but cultivars that consistently produce large berries over multiple harvests are needed [13]. In a study comparing sensory and instrumental qualities of blueberries, Saftner et al. [22] found that sensory scores for appearance were best correlated with berry size. In other words, consumers prefer larger berries. The sensory qualities, such as berry size, color, size, and taste are likely the most influential factor on blueberry preference in farmers' markets [24]. Customers of farmers' markets expect higher quality produce, but are also willing to pay premium prices [6].

Berry color is an important factor of fruit quality, and deep-blue berries with a waxy coat, producing a light-blue berry tend to be the most desirable [5] [26]. Blueberries are deep purple to black, but the berries are covered by a glaucous covering, giving blueberries their bluish color [5]. Berry color is affected by both the total anthocyanin content coupled with the quantity and structure of the waxy coating and is a highly complicated attribute [27]. The color is highly influenced by the state of the epicuticular wax found on the berries and the presence of rodlet wax structures, which are responsible for the light blue color found on some blueberries [26]. Generally, the lack of a waxy bloom is an indicator of post-harvest mishandling or overripe berries [26].

A blueberry's taste is a component of several factors, particularly the aromatic volatiles, SSC, TA, and the SSC/TA ratio [22]. It is difficult to accurately rate flavor, but blueberries should have a good balance of sugar to acid with a good aftertaste [5]. The tangy taste in blueberry is due partially to the tartness which counterbalances the sweetness [5]. Austin and Bondari [5] determined that high soluble solids content with low acid tended to be a pleasant tasting berry, but that low total acid negatively affects storage capacity. Soluble solids, $\mathrm{pH}$, and SSC/TA ratio have been shown to be correlated with berry deterioration, but the SSC/TA ratio is the best indicator [5]. Rabbiteye blueberries are tart when they first turn blue, and often get a negative image in the marketplace because fruit 
are often picked at this stage [2]. Berry maturity at harvest is one of the main factors affecting storage life and berry quality, as berries do not continue to ripen after harvest. Ultimately there must be a compromise between ensuring the optimum eating quality and providing the flexibility needed for marketing as well as transportation [26].

Rabbiteye blueberries tend to be more resistant than highbush to postharvest decay, and they also typically have a smaller, dry picking scar [27]. This scar is considered to be the primary path of entry for postharvest decay organisms, thus a small, dry picking scar is a desirable fruit characteristic [27] [28]. Large berries with small, dry picking scars are the most desirable, but cultivars that produce larger berries often produce larger picking scars [28].

This study is aimed to evaluate the performance of 11 new releases and well-established rabbiteye blueberry cultivars in North Alabama. Science-based cultivar evaluation will help growers select the best suited blueberry cultivars for their growing location and targeted market, to sustain blueberry production, and can lead to increased profits. There is limited information available on blueberry cultivar performance in Alabama and particularly in North Alabama. A study by Dozier et al. [29] conducted nearly two decades ago in southern Alabama evaluated several rabbiteye cultivars, but information is lacking on the performance of newly released rabbiteye cultivars in various locations throughout the state. Our objective in this study is to evaluate the vegetative growth and development, yield potential, and fruit quality of newly released and well-established rabbiteye blueberry cultivars for their performance in Alabama.

\section{Materials and Methods}

Eleven rabbiteye blueberry cultivars planted in Cullman, AL (lat. $34^{\circ} 11^{\prime} \mathrm{N}$, long. $\left.-86^{\circ} 47^{\prime} \mathrm{E}\right)$, USDA Hardiness Zone 7B, at the North Alabama Experiment Station were utilized in this experiment. The older cultivars studied included "Baldwin", "Climax", "Brightwell", "Powderblue", and "Premier", and the newer releases tested were "Alapaha", "Ira”, "Montgomery", “Onslow", and "Yadkin". The experimental design was a randomized complete block design with 6 replications and 2 plants per replications, with a total of 132 plants in the experimental plot.

The blueberries were planted in the fall of 2007, and the 2009 and 2010 seasons were considered the initial cropping seasons. Three-year rooted cuttings were used and standard commercial practices were implemented for the planting and maintenance of the bushes [30]. At planting, 18.9 L of peat moss were incorporated into the planting holes and $15.2 \mathrm{~cm}$ of pine bark mulch were added to amend the soil. Supplemental irrigation was installed to ensure successful plant establishment and production using drip tape. Plants were fertilized 3 times a year in April, May, and June using $0.1 \mathrm{~kg}$ of a 14-5-10 custom blueberry blend fertilizer (Southern States Cooperative, Inc.) in 2007 and 2008. Ammonium sulfate $\left(\left(\mathrm{NH}_{4}\right)_{2} \mathrm{SO}_{4}\right)$ was applied at a rate of $0.2 \mathrm{~kg}$ per plant at the start of the growing season, and an additional application was made after fruiting. 
Blueberry flowering was recorded by visually rating the percentage of fully open flowers on each bush at 7 day intervals. A flower was considered fully open when the stigma was observed protruding from the bell of the flower, and observations began when all cultivars were estimated to have at least $5 \%$ of the flowers fully open and continued until all experimental bushes reached 95\% open flowers.

In April of 2009, the crop experienced damage from a late season frost, and damage was estimated based on a 5 point scale representing the percentage of flowers damaged on each bush $(0=0 \%-5 \%, 1=6 \%-20 \%, 2=21 \%-40 \% .3=$ $41 \%-60 \%, 4=61 \%-80 \%$, and $5=81 \%-100 \%$ ).

Flower bud density was determined as a number of flower buds per cane cross sectional area $\left(\mathrm{cm}^{2}\right)$ in 2009. The diameters of 2 canes per bush, with a diameter between 1.0 and $3.0 \mathrm{~cm}$, were measured and flagged, and the number of flowers was counted on each cane. Flower bud density was expressed by the number of flower buds per unit cross sectional area. Due to an increase in plant size and crop load, this method was not feasible in the 2010 season, when fruit set was determined by flagging 2 fruiting shoots of a similar size (between 20 and $60 \mathrm{~cm}$ length) on each bush. The length of the fruiting shoot was measured and the fruit were counted. The shoot length was divided by the number of fruit set in order to determine the number of fruit per unit fruiting shoot. To obtain the initial fruit set, data was collected in May, and then the same shoots were counted again just before harvest in late June to determine the final fruit set.

Experimental bushes were hand-harvested on a weekly basis, starting when approximately $50 \%$ of the berries on the bush were fully colored, and bushes without a significant number of ripe berries were not harvested. Yield data were recorded on each harvest date for each experimental plant. In addition to determining the average yield per bush per harvest, the average total yields per bush were determined across both seasons.

Berry subsamples were collected from each harvested bush to determine cultivar fruit qualities characteristics. Berries were placed in a cooler and kept at $4^{\circ} \mathrm{C}$ before analysis. A $20 \mathrm{~g}$ subsample from each plant harvested was stored at $-80^{\circ} \mathrm{C}$ for later determination of soluble solids content (SSC), titratable acidity (TA), and $\mathrm{pH}$.

The fruit quality analysis was performed by measuring berry surface color, average fruit weight, firmness, number of berries with wet scar, berry dry weight, soluble solids content (SSC), titratable acidity (TA), the SSC/TA ratio, and $\mathrm{pH}$. The average berry weight was determined on a 50 berry subsample/bush. Fruit firmness was determined on a 10 berry subsample/bush using a handheld FT 02 penetrometer (McCormick Scientific, Richmond, IL) using a $1.5 \mathrm{~mm}$ probe. According to NeSmith [31] berries that have firmness exceeding $175 \mathrm{~g} / \mathrm{mm}$ are likely a good threshold for berries that are suitable for mechanical harvesting. Fruit were held stationary between the thumb and index finger on a flat surface, and the probe was pressed against the fruit in a slow and steady motion until the 
berry was pierced. The percentage of berries with wet picking scar was determined by examining a 50 berry subsample per bush. Berry dry weight (g) was determined by drying 10 berry subsample/bush at $77^{\circ} \mathrm{C}$ in a Grieve model sc-350 oven (Grieve Corporation, Round Lake, IL, USA) for 36 hours, and then the berry weight was recorded.

SSC, TA, and $\mathrm{pH}$ were determined using a method described by Vinson et al. [32]. SSC was determined by first pureeing approximately $20 \mathrm{~g}$ of frozen fruit and $20 \mathrm{ml}$ of HPLC water, obtained from a Millipore Direct-Q 5 filter system (Millipore Corp., Bedford, MA), using a ceramic mortar and pestle into a homogeneous liquid [32]. The resulting liquid was analyzed using a digital refractometer (Pal-1 Atago, Co., Tokyo, Japan) to determine the \% SSC at room temperature. To determine TA, the homogeneous liquid was clarified with a centrifuge at $15,000 \mathrm{~g}_{\mathrm{n}}$ at $4^{\circ} \mathrm{C}$ for 20 minutes (Model J2-21; Beckman Centrifuge, San Antonio, TX), and the supernatant was filtered with double-layered cheese cloth. The resulting supernatant was brought to a final volume of $40 \mathrm{~mL}$ with HPLC water and thoroughly mixed. Five $\mathrm{mL}$ of supernatant were diluted to a final volume of $30 \mathrm{~mL}$ with HPLC water, which was used to determine TA with an automated titrimeter (MetrohmTitrino Model 751GDP and Metrohm Sample Changer; Metrohm Corp., Herisau, Switzerland). The titrimeter was maintained at $10^{\circ} \mathrm{C}$ in a Fisher Scientific refrigerated chromatography chamber (Model Isotemp Laboratory Refrigerators; Fisher Scientific, Raleigh, NC). A 0.1 M solution of $\mathrm{NaOH}$ was titrated to an end point of $\mathrm{pH}$ 8.1. The results were expressed as citric acid equivalent through the following formula: $\left[\left(\mathrm{mL} \mathrm{NaOH} \times 0.1 \mathrm{~N} \times 0.064 \mathrm{meq} \cdot \mathrm{g}^{-1}\right.\right.$ of juice $\left.) \times 100\right]$. SSC: TA ratio was determined by dividing SSC by TA. The titrimeter also determines the $\mathrm{pH}$ of the sample used to determine the TA [32].

Ten berry subsamples from each harvested bush from each harvest date were analyzed to determine the external fruit color. A Minolta CM-2002 Spectrophotometer (Minolta, Tokyo, Japan), using the CIELAB color space $\left(L^{*}, a^{*}, b^{*}, C\right.$, $\mathrm{h}^{\circ}$ ) was utilized. The CIELAB color space can be visualized as a three dimensional graph, and equal distances on this graph represent visually equal distances in color differences [33] [34]. $\mathrm{L}^{*}$ can be visualized as the $\mathrm{z}$ axis, $\mathrm{L}^{*}$ indicates an objects lightness on a 0 to 100 scale, with 0 representing black and 100 representing white [33] [34]. Hue is represented by $a^{*}$ and $b^{*}$, and $a^{*}$ can be visualized as the horizontal coordinate ( $\mathrm{x}$ axis), and a positive $\mathrm{a}^{\star}$ indicates purplish-red, a negative $\mathrm{a}^{*}$ indicates bluish-green [33] [34]. The $\mathrm{b}^{*}$ represents the vertical coordinate ( $y$ axis), and a positive $b^{*}$ indicates yellow, while a negative $\mathrm{b}^{*}$ indicates blue [33] [34]. A more appropriate way to represent these readings is through the use of Chroma $\left(C^{\star}\right)$ and hue angle $\left(h^{\circ}\right)$, as these values are less likely to be misinterpreted [33]. Chroma indicates the saturation or intensity of the color, and the $C^{\star}$ value represents the distance from the origin to the $\left(a^{\star}, b^{\star}\right)$ coordinates [33]. The hue angle $\left(h^{\circ}\right)$ is easier to visualize than $a^{*}$ and $b^{*}$ values, as on a $360^{\circ}$ color wheel red-purple corresponds to an angle of $0^{\circ}$, yellow corresponds to an angle of $90^{\circ}$, bluish-green corresponds to $180^{\circ}$, and blue corresponds 
to an angle of $270^{\circ}$ [33]. The berry wax is evaluated by analyzing the $\mathrm{L}^{\star}$ values [5], and the color of the berries were evaluated by analyzing the $\mathrm{C}^{\star}$ and $\mathrm{h}^{\circ}$ [5].

Cultivar vegetative characteristics were evaluated by determining leaf area, chlorophyll readings, and plant growth index. Average leaf area was based on a 30 leaf sample per bush collected late summer and measured with a Licor LI-3100 area meter (Lincoln, NB, USA). Mature leaves located at least 5 nodes away from the terminal bud were used. Chlorophyll readings were taken on 10 leaves per experimental bush. Mature leaves located at least 5 nodes back from the terminal bud were used. Bush heights, as well as the plant width measured perpendicularly and diagonally to the planting row were measured to determine plant growth index of each experimental plant.

Since the experiment was designed as a completely randomized complete block design, fruit and yield characteristic data were based on all measurements across the harvest season as a whole, regardless of harvest date. All experimental data was analyzed using PROC GLIMMIX [35]. Mean separations were carried out using the Bonferroni mean separation test. The significance levels were represented by ${ }^{\star}(0.05),{ }^{*}(0.01)$, and ${ }^{* *}(0.001)$ respectively, and $P$-values $\leq$ 0.05 were deemed insignificant. Vegetative, flowering, and fruit set characteristic measurements were analyzed individually.

\section{Results and Discussion}

In the 2009 flowering season, 5\% flowering stage began on March 23 and on April 7 all of the cultivars under test had over $60 \%$ open flowers. A week later, on April 14, all cultivars had more than over $90 \%$ open flowers (Figure 1). "Baldwin", "Montgomery", and "Onslow" flowering stage was the most advanced on March 24, when "Tifblue" had the least open flowers. Flowering began approximately 2 weeks later in the 2010 season, but was condensed into 3 weeks as opposed to 5 weeks in 2009 (Figure 1, Figure 2). In the 2010 season, the 5\% flowering stage began on April 7 and all cultivars were found to be at $100 \%$ full

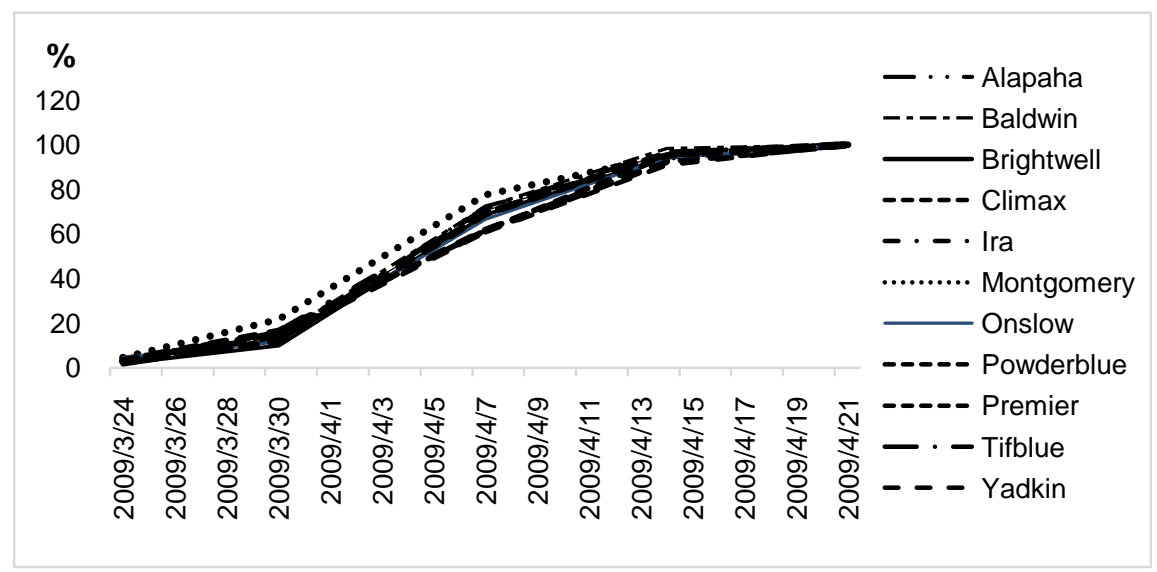

Figure 1. Percent open flowers of selected rabbiteye blueberry cultivars grown at the NAHRC, Cullman, AL, 2009. 


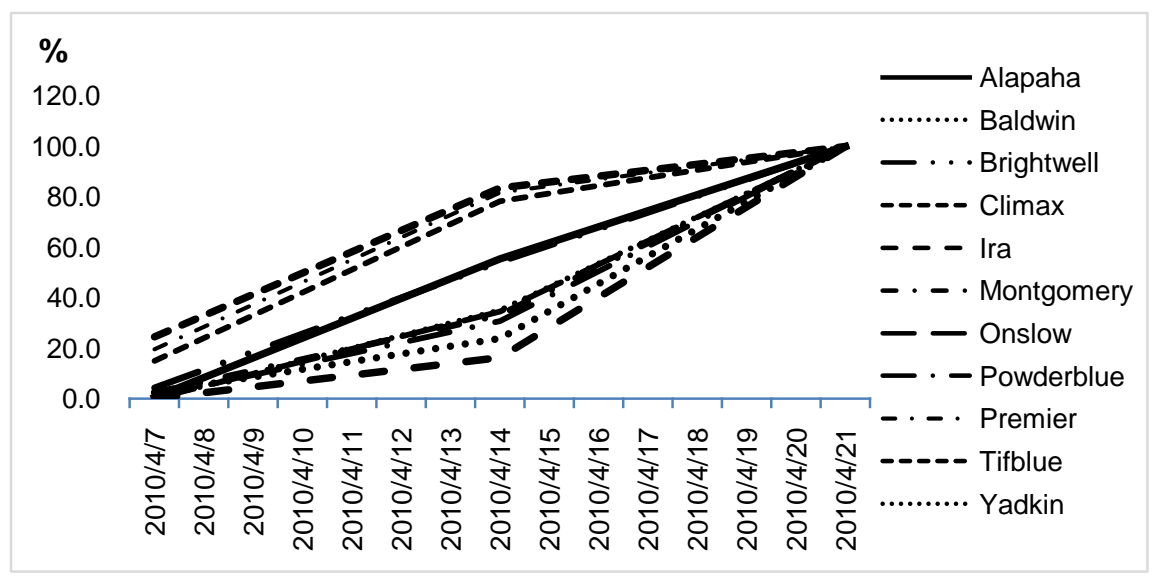

Figure 2. Percent open flowers of selected rabbiteye blueberry cultivars grown at the NAHRC, Cullman, AL, 2010.

bloom on April 21st. "Climax" was found to have the highest percentage of open flowers on April 7, when nearly $25 \%$ of its flowers were fully open. "Premier" and "Tifblue" also had a high percent of open flowers on April 7.

"Ira", "Onslow", and "Yadkin" did not reach the 5\% flowering stage until April 14. "Climax" again had the highest percentage of fully open flowers (80\%), and "Premier" and "Tifblue" flowering rates were not found to be different from "Climax". "Alapaha" and "Brightwell" were found to have over 50\% fully opened flowers on April 14, when "Ira" only had 16\% fully open flowers.

No differences were observed across cultivars with respect to the percentage of frost damaged flowers in 2009 (Table 1).

In June, "Premier" was found to have the highest number of flower buds, based on the fruit set density expressed as a number of flower buds $/ \mathrm{cm}^{2}$ cane cross sectional area (CCSA) in 2009 (Table 2). "Alapaha", "Baldwin", "Brightwell", "Climax", "Montgomery", "Tifblue", and "Yadkin" were not found to be different with respect to flower bud density from "Premier" ranging from 0.16 fruit per $\mathrm{cm}^{2}$ to 0.22 fruit per $\mathrm{cm}^{2}$. "Onslow" was the cultivar with the lowest flower bud number per $\mathrm{cm}^{2}$ CCSA. The initial fruit set count was made on May 24, 2010 and the final fruit set was determined on June 19. "Baldwin" was found to have the highest initial number of fruit set with 3.2 fruit per cm fruiting wood (Table 2).

"Alapaha" and "Brightwell" also had a high initial fruit set number of 2.8 fruit/cm fruiting wood, while "Ira" and "Tifblue" had the lowest initial fruit set of 1.9 and 2.0 fruit/cm fruiting wood respectively. Fruit loss based on the initial and final fruit set number ranged from 0.1 and 0.2 fruit per $\mathrm{cm}$ fruiting wood, which is considered negligible.

The earliest ripening varieties in both years were "Alapaha", "Climax", and "Premier" (Figure 3). "Brightwell", "Montgomery", and "Tifblue" had an intermediate ripening period beginning on June 22, and ending on July 16, in 2009. "Baldwin", "Ira", "Onslow", "Powderblue", and "Yadkin" matured late in 2009. In 2010, "Brightwell" and "Tifblue" also started their ripening early in the season. 
Table 1. Percentage frost damaged fully open flowers of selected rabbiteye blueberry cultivars grown at the NAHRC, Cullman, AL, 2009.

\begin{tabular}{cc}
\hline Cultivar & Percent frost damaged flowers $^{\mathrm{z}}$ \\
Alapaha & 0.1 \\
Baldwin & 0.8 \\
Brightwell & 0.8 \\
Climax & 0.6 \\
Ira & 0.2 \\
Montgomery & 1.1 \\
Onslow & 0.3 \\
Powderblue & 0.2 \\
Premier & 0.1 \\
Tifblue & 0.8 \\
Yadkin & 0.4 \\
$P$-value & 0.4413 \\
Significance & $\mathrm{N} . \mathrm{S}$. \\
\hline
\end{tabular}

${ }^{z} 0=0 \%-5 \%, 1=6 \%-20 \%, 2=21 \%-40 \%, 3=41 \%-60 \%, 4=61 \%-80 \%, 5=81 \%-100 \%$. N.S., ${ }^{*},{ }^{* *},{ }^{* * *}$ Indicates nonsignificant and significant differences at $P \leq 0.05,0.01$ or 0.001 respectively.

Table 2. Flower bud density, initial and final fruit set density of selected rabbiteye blueberry cultivars grown at the NAHRC, Cullman, AL, 2009-2010.

\begin{tabular}{|c|c|c|c|}
\hline Cultivar & $\begin{array}{c}\text { Number of flower } \\
\text { buds/CCSA, }\left(\mathrm{No} . / \mathrm{cm}^{2}\right)\end{array}$ & $\begin{array}{c}\text { Initial number of fruit } \\
\text { set/fruiting wood, }(\mathrm{No} . / \mathrm{cm})^{z}\end{array}$ & $\begin{array}{c}\text { Final number of fruit } \\
\text { set/fruiting wood, }(\text { No./cm })^{z}\end{array}$ \\
\hline & 2009 & \multicolumn{2}{|c|}{2010} \\
\hline Alapaha & $0.22 \mathrm{abc}$ & $2.8 \mathrm{ab}$ & $2.7 \mathrm{ab}$ \\
\hline Baldwin & $0.22 \mathrm{ab}$ & $3.2 \mathrm{a}$ & $3.0 \mathrm{a}$ \\
\hline Brightwell & $0.16 \mathrm{abc}$ & $2.8 \mathrm{ab}$ & $2.6 \mathrm{ab}$ \\
\hline Climax & $0.19 a b c$ & $2.3 \mathrm{bc}$ & $2.2 \mathrm{bc}$ \\
\hline Ira & $0.14 b c$ & $1.9 \mathrm{c}$ & $1.8 \mathrm{c}$ \\
\hline Montgomery & $0.16 \mathrm{abc}$ & $2.4 \mathrm{bc}$ & $2.3 \mathrm{bc}$ \\
\hline Onslow & $0.13 \mathrm{c}$ & $2.6 \mathrm{abc}$ & $2.4 \mathrm{abc}$ \\
\hline Powderblue & $0.13 b c$ & $2.3 \mathrm{bc}$ & $2.2 \mathrm{bc}$ \\
\hline Premier & $0.24 \mathrm{a}$ & $2.1 \mathrm{bc}$ & $2.0 \mathrm{bc}$ \\
\hline Tifblue & $0.22 \mathrm{ab}$ & $2.0 \mathrm{c}$ & $1.9 \mathrm{c}$ \\
\hline Yadkin & $0.20 \mathrm{abc}$ & $2.5 \mathrm{abc}$ & $2.4 \mathrm{abc}$ \\
\hline$P$-value & $<0.0001$ & $<0.0001$ & $<0.0001$ \\
\hline Significance & $* * *$ & $* * *$ & $* * *$ \\
\hline
\end{tabular}

${ }^{z}$ Based on 2 canes/plant. N.S., ${ }^{*}{ }^{* *},{ }^{* *}$ Nonsignificant and significant at $P \leq 0.05,0.01$ or 0.001 respectively. 


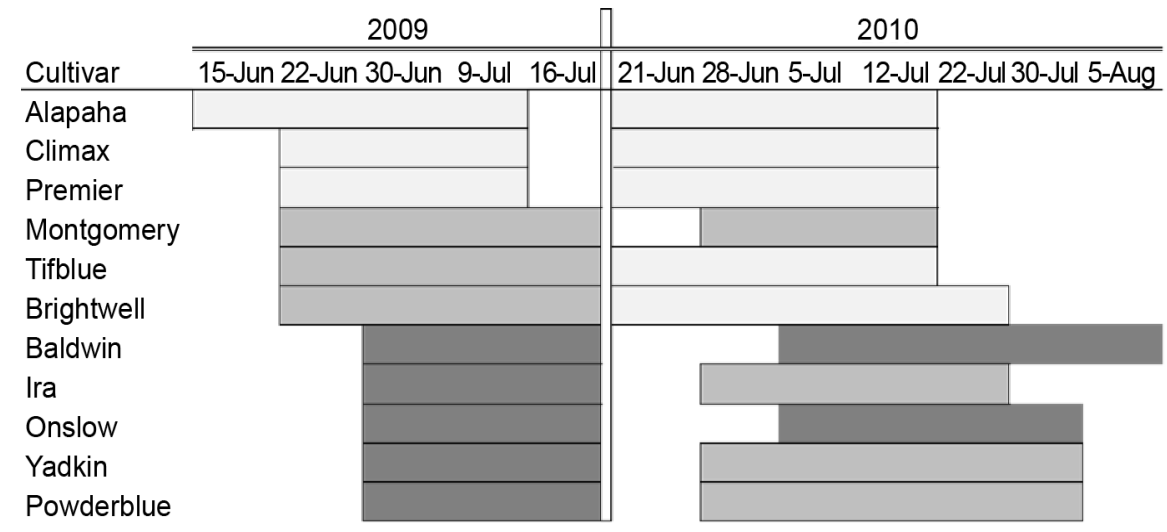

Figure 3. Season of ripening of selected rabbiteye blueberry cultivars grown at the NAHRC, Cullman, AL, 2009 and 2010.

"Ira", "Montgomery", "Powderblue", and "Yadkin" had an intermediate ripening period beginning on June 28, and ending on July 16, 2010. "Baldwin" and "Onslow" matured late in the season, between July 5, and August 5 in 2010. Additionally, "Baldwin", "Brightwell", and "Powderblue" also had an extended harvest season, lasting up to 5 weeks, or one additional week more than the other cultivars.

In 2009, all cultivars yielded between 1.0 and $1.2 \mathrm{~kg}$ per bush (Table 3), and no difference in yield between cultivars tested was found in 2009. In 2010, "Tifblue" was the highest yielding cultivar, producing $2.4 \mathrm{~kg} / \mathrm{bush}$, followed by "Alapaha", "Brightwell", Climax, and "Premier" which yielded between 2.0 and $2.3 \mathrm{~kg} /$ bush (Table 3). "Montgomery" was the lowest producer in 2010, $1.6 \mathrm{~kg}$ per plant, and the fruit yield of all cultivars, with the exception of "Tifblue" were not different. No differences in cumulative yield across both seasons were observed among cultivars (Table 3 ).

In both years of this study, differences in mean berry weight were found between tested cultivars. "Onslow" had the largest average berry of $1.5 \mathrm{~g}$ in both years, and "Alapaha" had the smallest berry of 0.9 and $1.0 \mathrm{~g}$ respectively (Table 3). Berries from "Baldwin", "Premier", and "Tifblue" were not different from those of "Onslow" in 2009, and "Montgomery", "Premier", "Brightwell", and "Ira" were not in 2010. "Ira" and "Powderblue" berries were not different in size from "Alapaha" in 2009, and "Baldwin" and "Powderblue" berry size did not differ from "Alapaha" in 2010.

"Climax" was found to have the highest dry berry weight in 2009, weighing 2.7 grams per 10 berries, and "Alapaha", Onslow", and "Powderblue" dry berry weight were lower, each averaging $2.4 \mathrm{~g}$ per 10 berry sample (Table 3). In 2010, "Onslow" had the greatest dry weight per 10 berries, weighing 3.4 per 10 berries, and "Brightwell, "Ira", "Premier", "Montgomery", and "Yadkin" were not lower (Table 3). "Alapaha" had the lowest dry berry weight, $1.9 \mathrm{~g}$.

"Brightwell" was found to have the firmest berry in 2009 and 2010, measuring 205 and $201 \mathrm{~g} / \mathrm{mm}$ (Table 4). "Climax" was not found to be different in either 
Table 3. Total yield per bush, cumulative yield, mean berry weight and mean berry dry weight of selected rabbiteye cultivars grown at the NAHRC, Cullman, AL, 2009 and 2010.

\begin{tabular}{|c|c|c|c|c|c|c|c|}
\hline Cultivar & $\begin{array}{l}\text { Mean berry } \\
\text { weight }(g)^{2}\end{array}$ & $\begin{array}{l}10 \text { berry dry } \\
\text { weight }(\mathrm{g})\end{array}$ & $\begin{array}{c}\text { Total } \\
\text { yield/bush }(\mathrm{kg})\end{array}$ & $\begin{array}{l}\text { Mean berry } \\
\text { weight }(\mathrm{g})^{\mathrm{z}}\end{array}$ & $\begin{array}{l}10 \text { berry dry } \\
\text { weight }(\mathrm{g})\end{array}$ & $\begin{array}{c}\text { Total } \\
\text { yield/bush }(\mathrm{kg})\end{array}$ & $\begin{array}{c}\text { Cumulative } \\
\text { yield/bush (kg) }\end{array}$ \\
\hline & & 2009 & & & 2010 & & \\
\hline Alapaha & $0.9 \mathrm{e}$ & $2.4 \mathrm{~b}$ & 0.8 & $1.0 \mathrm{e}$ & $1.9 \mathrm{e}$ & $2.1 \mathrm{ab}$ & 10.4 \\
\hline Baldwin & $1.5 \mathrm{ab}$ & $2.5 \mathrm{ab}$ & 0.9 & $1.2 \mathrm{de}$ & $3.0 \mathrm{bcd}$ & $1.6 \mathrm{~b}$ & 8.9 \\
\hline Brightwell & $1.2 \mathrm{~d}$ & $2.6 \mathrm{ab}$ & 2.0 & $1.4 \mathrm{ab}$ & $3.2 \mathrm{ab}$ & $2.0 \mathrm{ab}$ & 11.6 \\
\hline Climax & $1.3 \mathrm{~cd}$ & $2.7 \mathrm{a}$ & 1.1 & $1.2 \mathrm{cde}$ & $2.6 \mathrm{~d}$ & $2.0 \mathrm{ab}$ & 9.2 \\
\hline Ira & $1.1 \mathrm{de}$ & $2.5 \mathrm{ab}$ & 1.1 & $1.4 \mathrm{abc}$ & $3.2 \mathrm{abc}$ & $1.7 \mathrm{~b}$ & 11.0 \\
\hline Montgomery & $1.3 \mathrm{bcd}$ & $2.4 \mathrm{ab}$ & 1.1 & $1.5 \mathrm{a}$ & $3.1 \mathrm{abcd}$ & $1.6 \mathrm{~b}$ & 7.9 \\
\hline Onslow & $1.5 \mathrm{a}$ & $2.4 \mathrm{~b}$ & 1.1 & $1.5 \mathrm{a}$ & $3.4 \mathrm{a}$ & $1.6 \mathrm{~b}$ & 8.7 \\
\hline Powderblue & $1.1 \mathrm{de}$ & $2.4 \mathrm{~b}$ & 0.9 & $1.2 \mathrm{de}$ & $2.8 \mathrm{~cd}$ & $1.6 \mathrm{~b}$ & 10.1 \\
\hline Premier & $1.4 \mathrm{abc}$ & $2.6 \mathrm{ab}$ & 0.8 & $1.4 \mathrm{ab}$ & $3.1 \mathrm{abcd}$ & $2.3 \mathrm{ab}$ & 10.3 \\
\hline Tifblue & $1.4 \mathrm{abc}$ & $2.5 \mathrm{ab}$ & 1.0 & $1.3 \mathrm{bcd}$ & $2.9 \mathrm{bcd}$ & $2.4 \mathrm{ab}$ & 11.3 \\
\hline Yadkin & $1.2 \mathrm{~cd}$ & $2.4 \mathrm{ab}$ & 1.1 & $1.3 \mathrm{bcd}$ & $3.0 \mathrm{abcd}$ & $1.6 \mathrm{~b}$ & 10.3 \\
\hline$P$-value & $<0.0001$ & 0.0022 & 0.5 & $<0.0001$ & $<0.0001$ & 0.0001 & 0.22015 \\
\hline Significance & $* * *$ & ** & N.S. & $* * *$ & $* * *$ & $* * *$ & n.s. \\
\hline
\end{tabular}

${ }^{\mathrm{z}}$ Based on a 50 berry sample per plant.

Table 4. Percent wet stem scar and fruit firmness of selected rabbiteye blueberry cultivars grown at the NAHRC, Cullman, AL, 2009 and 2010.

\begin{tabular}{|c|c|c|c|c|}
\hline Cultivar & Wet scar $(\%)^{z}$ & Fruit firmness $(\mathrm{g} / \mathrm{mm})^{\mathrm{y}}$ & Wet scar $(\%)^{\mathrm{z}}$ & Fruit firmness $(\mathrm{g} / \mathrm{mm})^{\mathrm{y}}$ \\
\hline & \multicolumn{2}{|c|}{2009} & \multicolumn{2}{|c|}{2010} \\
\hline Alapaha & $1.0 \mathrm{~b}$ & $172.8 \mathrm{def}$ & $2.1 \mathrm{bc}$ & $168.8 \mathrm{f}$ \\
\hline Baldwin & $3.0 \mathrm{a}$ & $181.1 \mathrm{cde}$ & $3.4 \mathrm{a}$ & $179.3 \mathrm{de}$ \\
\hline Brightwell & $1.6 \mathrm{~b}$ & $204.6 \mathrm{a}$ & $1.9 \mathrm{bc}$ & $201.3 \mathrm{a}$ \\
\hline Climax & $1.4 \mathrm{~b}$ & $201.7 \mathrm{ab}$ & $1.8 \mathrm{bc}$ & $193.9 \mathrm{ab}$ \\
\hline Ira & $1.0 \mathrm{~b}$ & $184.9 \mathrm{~cd}$ & $1.7 \mathrm{bc}$ & $185.4 \mathrm{~cd}$ \\
\hline Montgomery & $1.4 \mathrm{~b}$ & $163.7 \mathrm{f}$ & $2.8 \mathrm{ab}$ & 172.1 ef \\
\hline Onslow & $1.4 \mathrm{~b}$ & $189.4 \mathrm{bc}$ & $1.6 \mathrm{bc}$ & $186.0 \mathrm{bcd}$ \\
\hline Powderblue & $0.9 \mathrm{~b}$ & $176.5 \mathrm{de}$ & $1.4 \mathrm{c}$ & 174.9 ef \\
\hline Premier & $1.7 \mathrm{ba}$ & $172.5 \mathrm{def}$ & $2.0 \mathrm{bc}$ & 176.6 ef \\
\hline Tifblue & $1.9 \mathrm{ba}$ & 171.7 ef & $2.4 \mathrm{abc}$ & $177.1 \mathrm{e}$ \\
\hline Yadkin & $1.0 \mathrm{~b}$ & $189.0 \mathrm{bc}$ & $1.3 \mathrm{c}$ & $188.8 \mathrm{bc}$ \\
\hline$P$-value & $<0.0001$ & $<0.0001$ & $<0.0001$ & $<0.0001$ \\
\hline Significance & $* * *$ & $* * *$ & $* * *$ & $* * *$ \\
\hline
\end{tabular}

${ }^{ }$Percentage based on a 50 berry sample per plant. ${ }^{\mathrm{y}}$ Average based on a 10 berry sample per plant. N.S., ${ }^{*}{ }^{* *}$, ${ }^{* *}$ Nonsignificant and significant at $P \leq 0.05$, 0.01 or 0.001 respectively. 
season, measuring $194 \mathrm{~g} / \mathrm{mm}$ and 202 respectively. "Montgomery" had the softest berry in 2009, measuring $164 \mathrm{~g} / \mathrm{mm}$, and "Alapaha" was found to have the softest berry in 2010, measuring $169 \mathrm{~g} / \mathrm{mm}$. "Alapaha", "Montgomery", and "Premier" had consistently softer berries across seasons, ranging from 164 to 173 $\mathrm{g} / \mathrm{mm}$ in 2009 and 169 to $177 \mathrm{~g} / \mathrm{mm}$ in 2010.

"Baldwin" had the highest percentage of berries with wet scar in both 2009 and $2010-3.0 \%$ and 3.4\% respectively, and "Tifblue" berries did not have a high percentage of berries with wet scar in either year (Table 4). In 2009, "Powderblue" had the lowest occurrence of wet scar on its berries, and all berries of cultivars except "Baldwin" did not show differences in wet scar occurrence. In 2010, "Yadkin" was found to have the lowest percentage of berries with wet scar.

In 2009, "Yadkin" berries had the highest $\mathrm{pH}$, measuring 3.65, but the majority of cultivars produced berries that did not have different $\mathrm{pH}$ values (Table 5). "Baldwin" and "Onslow" both had lower pH of 3.34 and 3.35 respectively. In 2010, all cultivars again fell within the acceptable range of 2.25 to 4.25 (Table 5). "Yadkin" berries again had the highest $\mathrm{pH}$, measuring 3.9, while "Brightwell", "Premier", and "Tifblue" berries had a lower $\mathrm{pH}$, measuring 3.80. "Baldwin" had the lowest $\mathrm{pH}$ of 3.62, while "Montgomery", "Onslow", and "Powderblue" were not found to differ.

In 2009 and 2010, all cultivars were found to have berries in the acceptable range except "Onslow", which had the lowest sugar content of 9.4\% in 2009 (Table 5). "Alapaha", "Climax", "Brightwell”, "Premier", "Tifblue", and "Yadkin" all had

Table 5. Soluble solids content (SSC), pH, total acidity (TA) and SSC/TA ratio of selected rabbiteye blueberry cultivars grown at the NAHRC, Cullman, AL, 2009-2010

\begin{tabular}{|c|c|c|c|c|c|c|c|c|}
\hline Cultivar & $\mathrm{pH}$ & SSC (\%) & TA (\%) & SSC/TA & $\mathrm{pH}$ & SSC (\%) & TA (\%) & SSC/TA \\
\hline & \multicolumn{4}{|c|}{2009} & \multicolumn{4}{|c|}{2010} \\
\hline Alapaha & $3.63 \mathrm{ab}$ & $14.5 \mathrm{ab}$ & 0.23 & 62 & $3.77 \mathrm{bc}$ & $15.1 \mathrm{bc}$ & 0.20 & 75 \\
\hline Baldwin & $3.34 \mathrm{c}$ & $12.0 \mathrm{bcd}$ & 0.44 & 27 & $3.62 \mathrm{f}$ & $14.5 \mathrm{f}$ & 0.32 & 46 \\
\hline Brightwell & $3.54 \mathrm{abc}$ & $13.7 \mathrm{ab}$ & 0.28 & 49 & $3.79 \mathrm{~b}$ & $15.2 \mathrm{~b}$ & 0.20 & 77 \\
\hline Climax & $3.51 \mathrm{abc}$ & $15.2 \mathrm{a}$ & 0.39 & 39 & $3.75 \mathrm{bcd}$ & $15.0 \mathrm{bcd}$ & 0.25 & 60 \\
\hline Ira & $3.5 \mathrm{abc}$ & $10 \mathrm{~d}$ & 0.30 & 33 & 3.74 bcde & $15.0 \mathrm{bcde}$ & 0.24 & 63 \\
\hline Montgomery & $3.48 \mathrm{abc}$ & $13.0 \mathrm{abc}$ & 0.33 & 40 & 3.65 ef & 14.6 ef & 0.28 & 52 \\
\hline Onslow & $3.35 \mathrm{c}$ & $9.4 \mathrm{~d}$ & 0.31 & 30 & $3.69 \mathrm{cdef}$ & $14.8 \mathrm{cdef}$ & 0.24 & 61 \\
\hline Premier & $3.54 \mathrm{abc}$ & $15.4 \mathrm{a}$ & 0.28 & 55 & $3.80 \mathrm{~b}$ & $15.2 \mathrm{~b}$ & 0.18 & 84 \\
\hline Tifblue & $3.51 \mathrm{abc}$ & $14.6 \mathrm{ab}$ & 0.40 & 37 & $3.80 \mathrm{~b}$ & $15.2 \mathrm{~b}$ & 0.45 & 34 \\
\hline Yadkin & $3.65 \mathrm{a}$ & $13.5 \mathrm{~b}$ & 0.23 & 60 & $3.91 \mathrm{a}$ & $15.6 \mathrm{a}$ & 0.18 & 86 \\
\hline$P$-value & $<0.0001$ & $<0.0001$ & 0.56 & & $<0.0001$ & $<0.0001$ & 0.50 & \\
\hline Significance & $* * *$ & $* * *$ & n.s. & & $* * *$ & $* * *$ & N.S. & \\
\hline
\end{tabular}

${ }^{z}$ Based on a 50 berry sample per plant. N.S., ${ }^{\star},{ }^{* *},{ }^{* *}$ Nonsignificant and significant at $P \leq 0.05,0.01$ or 0.001 respectively. 
higher sugar contents in both years, and "Baldwin", "Montgomery, "Onslow", and "Powderblue" all were found to have lower sugars in both 2009 and 2010. "Premier" was found to have the highest SSC in 2009 at 15.4\%, and "Onslow" had the lowest sugar content, 9.4\%. "Baldwin", "Ira", and "Powderblue" were not found to differ in sugar content. In 2010, "Yadkin" had the highest SSC, measuring 15.6\%, and "Baldwin" had the lowest sugar content, with an SSC of 14.5\% (Table 5). "Brightwell", "Premier", and "Tifblue" all had high sugar levels as well, each with just over 15\% SSC, and the sugar content of "Montgomery", "Onslow", and "Powderblue" was not different from "Baldwin".

In 2009 "Alapaha" and "Yadkin" berries were the least acidic and below the optimal range, with TA measuring $0.2 \%$ (Table 5). "Baldwin" was found to have the most acidic berries, with a TA of $0.4 \%$. "Baldwin", "Montgomery", "Powderblue", and "Tifblue" were found to fall into the accepted range in 2010, with TA ranging between $0.3 \%$ and $0.5 \%$, and all other cultivars fell slightly below this range (Table 5). However, no differences were observed across cultivars for the 2010 season for berry TA.

In 2009, "Baldwin", with a SSC/TA ratio of 27; "Onslow", 30; "Powderblue", 33; and "Ira", 33 fell within this range (Table 5). The remaining cultivars had SSC/TA ratios ranging from 37 to 62, and Alapaha had the highest ratio at 62 . "Yadkin" had the highest ratio of 86 in 2010, and "Premier" also had a high ratio of 84 (Table 5). "Montgomery" had the lowest ratio of 52. None of the cultivars were found to have ratios within the described optimal range in 2010. The high ratios in 2010 are likely due to the low acid content of the berries.

"Powderblue" had the lightest berry skin in both years, with lightness $\left(\mathrm{L}^{*}\right)$ measurements of 32.45 and 36.74 respectively (Table 6). "Baldwin", "Ira", and "Yadkin" had consistently darker berries across 2009 and 2010 with $L^{*}$ ranging from 25.61 to 30.61 (Table 6). "Powderblue" had the most intensely colored berries, or highest chroma $\left(C^{*}\right)$ in both seasons, 4.10 in 2009 and 5.84 in 2010 (Table 6). "Premier" and "Tifblue" had intensely colored berries across seasons. "Alapaha" berries were found to have the lowest $C^{\star}$ in both years, 2.22 and 3.63 respectively. In 2009 , the $h^{\circ}$ angle of the berries fell between bluish-green $\left(180^{\circ}\right)$ and blue $\left(270^{\circ}\right)$ (Table 6).

"Yadkin" was found to have the most blue berry skin in 2009, and "Alapaha" berries were found to be greener. All other cultivars tested were not found to be different than "Yadkin" in terms of their skin color hue angle. In 2010, the $\mathrm{h}^{\circ}$ angel of the berries of all cultivars in test fell between blue $\left(270^{\circ}\right)$ and red-purple $\left(360^{\circ}\right)$. "Powderblue" berries were the most blue in 2010, and "Onslow" berries were the most red-purple. "Alapaha", "Baldwin", and "Brightwell" were not found to be different than "Onslow" in 2010.

No differences were observed among cultivars with regards to plant growth index (PGI) (Table 7). In both 2009 and 2010, "Yadkin" was found to have the greatest leaf area, measuring 17.4 and $13.7 \mathrm{~cm}^{2}$ (Table 7). "Alapaha", "Baldwin", "Brightwell", "Climax", and "Ira" had smaller leaf area in both seasons. In 2009, 
Table 6. Fruit lightness $\left(\mathrm{L}^{\star}\right)$, chroma $\left(\mathrm{C}^{\star}\right)$, and hue angle $\left(\mathrm{h}^{\star}\right)$ of selected rabbiteye blueberry cultivars grown at the NAHRC, Cullman, 2009-2010².

\begin{tabular}{|c|c|c|c|c|c|c|}
\hline Cultivar & $\mathrm{L}^{*}$ & $\mathrm{C}^{*}$ & $\mathrm{~h}^{\circ}$ & $\mathrm{L}^{*}$ & $\mathrm{C}^{*}$ & $\mathrm{~h}^{\circ}$ \\
\hline & \multicolumn{3}{|c|}{2009} & \multicolumn{3}{|c|}{2010} \\
\hline Alapaha & $28.94 \mathrm{~cd}$ & $2.22 \mathrm{~d}$ & $233.0 \mathrm{~b}$ & 29.97 ef & $3.63 \mathrm{~g}$ & $280.2 \mathrm{abc}$ \\
\hline Baldwin & $27.67 \mathrm{e}$ & $2.88 \mathrm{c}$ & $263.8 \mathrm{a}$ & $28.96 \mathrm{f}$ & $4.58 \mathrm{de}$ & $280.5 \mathrm{ab}$ \\
\hline Brightwell & $27.95 \mathrm{de}$ & $2.94 \mathrm{c}$ & $263.5 \mathrm{a}$ & $31.41 \mathrm{~cd}$ & $4.82 \mathrm{~cd}$ & $281.6 \mathrm{ab}$ \\
\hline Climax & $29.6 \mathrm{c}$ & $3.40 \mathrm{~b}$ & $258.9 \mathrm{a}$ & $31.53 \mathrm{~cd}$ & $4.53 \mathrm{de}$ & $276.7 \mathrm{de}$ \\
\hline Ira & $26.56 \mathrm{f}$ & $2.28 \mathrm{~d}$ & $260.2 \mathrm{a}$ & $30.61 \mathrm{de}$ & $4.45 \mathrm{e}$ & $278.3 \mathrm{~cd}$ \\
\hline Montgomery & $29.19 \mathrm{c}$ & $2.89 \mathrm{c}$ & $260.5 \mathrm{a}$ & $32.62 \mathrm{bc}$ & $4.92 \mathrm{c}$ & $277.3 \mathrm{de}$ \\
\hline Onslow & $27.94 \mathrm{de}$ & $2.68 \mathrm{c}$ & $261.2 \mathrm{a}$ & $33.44 \mathrm{~b}$ & $4.09 \mathrm{f}$ & $281.9 \mathrm{a}$ \\
\hline Powderblue & $32.45 \mathrm{a}$ & $4.10 \mathrm{a}$ & $262.5 \mathrm{a}$ & $36.74 \mathrm{a}$ & $5.84 \mathrm{a}$ & $272.2 \mathrm{f}$ \\
\hline Premier & $31.03 \mathrm{~b}$ & $3.65 \mathrm{~b}$ & 258.9 a & $31.87 \mathrm{c}$ & $5.09 \mathrm{bc}$ & $276.0 \mathrm{e}$ \\
\hline Tifblue & $31.36 \mathrm{~b}$ & $3.51 \mathrm{~b}$ & 258.9 a & $31.49 \mathrm{~cd}$ & $5.24 \mathrm{~b}$ & $275.6 \mathrm{e}$ \\
\hline Yadkin & $25.61 \mathrm{f}$ & $2.29 \mathrm{~d}$ & $266.8 \mathrm{a}$ & $29.54 \mathrm{ef}$ & $4.39 \mathrm{e}$ & $279.7 \mathrm{bc}$ \\
\hline$P$-value & $<0.0001$ & $<0.0001$ & $<0.0001$ & $<0.0001$ & $<0.0001$ & $<0.0001$ \\
\hline Significance & $* * *$ & $* * *$ & $* * *$ & $* * *$ & $* * *$ & $* * *$ \\
\hline
\end{tabular}

${ }^{\mathrm{z}}$ Measured in CIELAB. $\mathrm{L}^{*}=$ lightness, $\mathrm{C}^{*}=$ chroma, $\mathrm{h}^{\circ}=$ hue angle $\left(0^{\circ}=\right.$ red-purple, $90^{\circ}=$ yellow, $180^{\circ}=$ bluish-green, $270^{\circ}=$ blue $)$. N.S., ${ }^{*},{ }^{* *},{ }^{* *}$ Nonsignificant and significant at $P \leq 0.05,0.01$ or 0.001 respectively.

Table 7. Plant growth index, leaf atrea, and chlorophyll content of selected rabbiteye blueberry cultivars grown at the NAHRC, Cullman, AL, 2009-2010.

\begin{tabular}{|c|c|c|c|c|c|c|}
\hline Cultivar & Plant growth index $\left(\mathrm{cm}^{3}\right)$ & Leaf Area $\left(\mathrm{cm}^{2}\right)^{\mathrm{z}}$ & Clorophylly & Plant growth index $\left(\mathrm{cm}^{3}\right)$ & Leaf Area $\left(\mathrm{cm}^{2}\right)^{\mathrm{z}}$ & Clorophyll ${ }^{y}$ \\
\hline & \multicolumn{3}{|c|}{2009} & \multicolumn{3}{|c|}{2010} \\
\hline Alapaha & 25644 & $13.1 \mathrm{bcd}$ & $46.6 \mathrm{ab}$ & 33273 & $10.71 \mathrm{~cd}$ & $46.2 \mathrm{ab}$ \\
\hline Baldwin & 33337 & $13.0 \mathrm{bcd}$ & 40.3 bcde & 42007 & $11.5 \mathrm{bcd}$ & $40.5 \mathrm{abc}$ \\
\hline Brightwell & 32379 & $12.1 \mathrm{~cd}$ & $48.0 \mathrm{a}$ & 38413 & $10.0 \mathrm{~d}$ & $46.8 \mathrm{a}$ \\
\hline Climax & 32609 & $10.9 \mathrm{~d}$ & $39.9 \mathrm{cde}$ & 38167 & $10.6 \mathrm{~cd}$ & $36.9 \mathrm{bc}$ \\
\hline Ira & 34419 & $11.1 \mathrm{~d}$ & $39.8 \mathrm{de}$ & 40225 & $11.1 \mathrm{~cd}$ & $40.4 \mathrm{abc}$ \\
\hline Montgomery & 36913 & $12 \mathrm{~cd}$ & $46.3 \mathrm{abc}$ & 43245 & $13.4 \mathrm{ab}$ & $46.4 \mathrm{ab}$ \\
\hline Onslow & 33477 & $12.9 \mathrm{bcd}$ & $46.9 \mathrm{a}$ & 41408 & $12.5 \mathrm{abc}$ & $46.4 \mathrm{ab}$ \\
\hline Powderblue & 27154 & $14.9 \mathrm{~b}$ & $44.9 \mathrm{abcd}$ & 34069 & $11.0 \mathrm{~cd}$ & $44.6 \mathrm{abc}$ \\
\hline Premier & 37723 & $13.9 \mathrm{bc}$ & 44.3 abcde & 49216 & $13.4 \mathrm{ab}$ & $44.4 \mathrm{abc}$ \\
\hline Tifblue & 41039 & $13.9 \mathrm{bc}$ & 42.0 abcde & 49400 & $12.4 \mathrm{abc}$ & $40 \mathrm{abc}$ \\
\hline Yadkin & 26275 & $17.4 \mathrm{a}$ & $38.0 \mathrm{e}$ & 35446 & $13.7 \mathrm{a}$ & $36.1 \mathrm{c}$ \\
\hline$P$-value & 0.1138 & $<0.0001$ & $<0.0001$ & 0.1005 & $<0.0001$ & $<0.0001$ \\
\hline Significance & N.S. & $* * *$ & $* * *$ & N.S. & $* * *$ & $* * *$ \\
\hline
\end{tabular}

${ }^{z}$ Average of 30 leaves per bush. ${ }^{y}$ Based on 10 readings per plant averaged. N.S., ${ }^{*},{ }^{* *}$, ${ }^{* * *}$ Nonsignificant and significant at $P \leq 0.05,0.01$ or 0.001 respectively. 
"Brightwell" had the highest chlorophyll levels (48.0), while "Alapaha", "Montgomery", "Onslow", "Powderblue", "Premier", and "Tifblue" were not found to differ (Table 7). "Yadkin" was the cultivar with the lowest chlorophyll level in 2009. In 2010, "Brightwell" had the highest chlorophyll content and only "Climax" and "Yadkin" had lower foliar chlorophyll levels.

"Yadkin" was found to have the most sprawling growth habit, but all cultivars except "Alapaha" and "Onslow" were not found to be different, with a form index ranging from 2.4 to 3.7 (Table 8). "Alapaha" had the most upright growth habit.

\section{Conclusions}

The 2010 results indicated that "Climax" and "Premier" are early flowering cultivars and thus might run the risk of damage due to late spring frost. "Alapaha" appears to bloom later, although it still has an early flowering habit, and thus may not be as prone to damage from late spring frost. Similarly, Dozier et al. [29] found "Climax" to be the earliest cultivar in their variety trial in central Alabama, as did NeSmith [13] in a Georgia variety trial. "Alapaha” was found to bloom just after "Climax" in Georgia as well [13].

"Baldwin" was shown to have a high fruit set in both experimental years, but this did not translate into high yields in either season. Fruit loss didn't seem to be an issue as indicated by the initial and final fruit set densities. Davies [14] states that decreases in fruit set, or fruit drop, tend to occur in the first three to four weeks after bloom and gradually decrease for the next few weeks. The initial

Table 8. Bush growth habit of selected rabbiteye blueberry cultivars grown at the NAHRC, Cullman, AL, 2010.

\begin{tabular}{cc}
\hline Cultivar & Bush form ${ }^{2}$ \\
Alapaha & $2.4 \mathrm{~b}$ \\
Baldwin & $2.8 \mathrm{a}$ \\
Brightwell & $2.9 \mathrm{a}$ \\
Climax & $2.4 \mathrm{~b}$ \\
Ira & $2.8 \mathrm{a}$ \\
Montgomery & $3.4 \mathrm{a}$ \\
Onslow & $2.4 \mathrm{~b}$ \\
Powderblue & $2.4 \mathrm{ab}$ \\
Premier & $2.4 \mathrm{ab}$ \\
Tifblue & $2.9 \mathrm{a}$ \\
Yadkin & $3.7 \mathrm{a}$ \\
$P$-value & $<0.0001$ \\
Significance & $* * *$ \\
\hline
\end{tabular}

${ }^{z} 1=$ Upright; $5=$ Sprawling. N.S., ${ }^{*, * *, * * *}$ Indicates nonsignificant and significant differences at $P<0.05$, 0.01 or 0.001 respectively. 
fruit set was determined in late May in 2010, which might have been too late, since the majority of fruit loss might already have occurred.

"Alapaha", "Climax", and "Premier" had early ripening seasons in both years of this study. These results suggest these cultivars are likely good selections for North Alabama for targeting early market production. Our data are in agreement with conclusions by NeSmith [13], who also found "Alapaha" and "Climax" to be the earliest ripening varieties in Georgia. "Baldwin" and "Onslow" matured late in the season, and would be good candidates for the extension of the blueberry harvest season in North Alabama. "Baldwin", "Brightwell", and "Powderblue" were found to have extended harvest seasons, which suggests they may be well suited for production at pick-your-own operations. Dozier et al. [29] also found that "Powderblue" had an extended 5 week harvest season in Alabama. Berries sold late in the season receive lower prices than berries sold in the early market, but a late ripening variety with an extended season has the benefit of extending the season as well as likely overlapping with other ripening seasons. "Baldwin" berries are not well suited for shipping, as they likely have a shorter shelf life than other cultivars tested, as indicated by low berry $\mathrm{pH}$ and high occurrence of picking scar, and likely should be considered for pick-your-own operations mainly.

Due to greater berry firmness, "Brightwell" and "Climax" may be better suited for shipping and mechanical harvesting as compared to the other cultivars tested. "Alapaha", "Montgomery", and "Premier" each had soft berries over both seasons. "Premier" was also found to produce the softest berries in a study by Itle and NeSmith [36]. These results coincide with the findings of NeSmith [13], who also found "Brightwell" and "Climax" to have the firmest berries of the rabbiteye blueberry cultivars tested in Georgia. Additionally, Silva et al. [27] found that "Climax" was the firmest berry of those tested in Mississippi. "Alapaha", "Onslow", and "Yadkin" were indicated to have a more upright growth habit in 2010, which is also desirable for mechanical harvest.

Berries with low acidity and high $\mathrm{pH}$ have good keeping quality [5], and a $\mathrm{pH}$ of 2.25 to 4.25 has been reported as acceptable [22]. Brightwell" and "Yadkin" berries may be well-suited for the shipped fresh market, as they has a firm berries and the high $\mathrm{pH}$. Firm berries ship well, and a high berry $\mathrm{pH}$ indicates a good shelf-life.

While no differences were seen across cultivars in 2009 with respect to yield per bush or in cumulative yield across both seasons, 2010 yield data indicate that "Alapaha", "Brightwell", "Premier", and "Tifblue" were high yielding cultivars. Late spring frost damage experienced in the Cullman region in 2009 may be accountable for the low crop of "Baldwin" and "Powderblue" cultivars. These coincide with findings by Dozier et al. [29], who concluded that "Tifblue" and "Premier" are highly productive cultivars in Central Alabama. Additionally, "Powderblue" was found to be a low producer in early years, eventually becoming one of the top producers [29].

Saftner et al. [22] states that soluble solids content (SSC) above $10 \%$ is accept- 
able for blueberry fruit. According to Gilbert et al., [37] consumers prefer sweet and intense berry flavor. All cultivars in our test produced berries with SSC over 10\%. "Premier" and "Climax" had the highest sugar content among all cultivars in our test. "Onslow" and "Baldwin" were found to have lower SSC in both years. "Yadkin" berries were least acidic and "Baldwin" berries were the most acidic in 2009, but differences were not observed in 2010. The acceptable range for total acidity (TA) in blueberry, according to Saftner [22], should vary between 0.3 and $1.3 \%$, and berries with high SS and low TA tend to have a pleasant taste. A high SSC/TA ratio is an indicator of a good tasting blueberry, and a high correlation has been found between this ratio and storage quality [5]. A ratio between 10 and 33 has been cited as an acceptable range for the SSC/TA ratio [22]. The low TA generally led to higher SSC/TA ratios and tastier berries in current study.

In both years, "Powderblue" had the lightest colored berry, which indicates the presence of a waxier surface [5] [26]. Additionally, "Powderblue" had the highest chroma, indicating the most saturated color, and the hue angle closest to blue $\left(270^{\circ}\right)$. In addition to color being an indicator of ripeness or post-harvest quality, deep-blue berries with a waxy coat, which produce a light-blue berry tend to be the most desirable [5] [26]. "Premier" and "Tifblue" both had colors that indicated high quality fruit in both years. Similarly, NeSmith [13] indicated that "Tifblue" was the most pleasantly colored berry of the cultivars tested in Georgia, and "Alapaha" to be the least desirable. In Mississippi grown rabbiteyes, Silva et al. [27] found that "Premier" and "Tifblue" had light berries with a hue angle indicating a highly blue colored berry as well. The pleasant colored berries found on "Powderblue", "Premier", and "Tifblue" make them good candidates for sale at farmers markets and the fresh market. "Powderblue" berries, however, tended to be small, which is not desirable for the fresh market. "Tifblue" and "Premier" produced large, pleasant colored berries. Silva et al. [27] found that "Climax", "Premier", and "Tifblue" all produced larger berries in a Mississippi cultivar trial than were seen in this study, producing berries ranging from 1.7 to $1.9 \mathrm{~g}$.

Nothing can be concluded from the PGI from either year, as no differences were found. Leaf area and chlorophyll readings did not clearly indicate which cultivars were most vigorous. "Yadkin" leaves were found to have the lowest chlorophyll but the highest leaf area, and conversely "Brightwell" leaves were found to have the highest chlorophyll levels and were smaller across seasons.

\section{References}

[1] Spiers, J.M. (1990) Rabbiteye Blueberry. Fruit Varieties Journal, 44, 68-72.

[2] Draper, A.D. (2007) Blueberry Breeding: Improving the Unwild Blueberry. Journal of the American Pomological Society, 61, 140-143.

[3] Miller-Butler, M.A., Curry, K.J., Smith, B.J. and Braswell, J. (2009) Seed Set, Fruit Weight and Yield in Highbush (Vaccinium corymbosum L.) Blueberry Cultivars 
"Duke" and "Bluecrop". Acta Horticulturae, 810, 369-377. https://doi.org/10.17660/ActaHortic.2009.810.48

[4] Esendugue, G.F., Krewer, G., Harrison, K. and Stanaland, D. (2008) Economic Returns Using Risk-Related Budget Analysis for Rabbiteye Blueberry in Georgia. HortTechnology, 18, 506-515.

[5] Austin, M.E. and Bondari, K. (1993) Fruit Quality Characteristics of Five Rabbiteye Blueberry Cultivars and Clones. Acta Horticulturae, 345, 133-140. https://doi.org/10.17660/ActaHortic.1993.345.18

[6] Kezis, A., Gewbu, T., Peavy, S. and Cheng, H. (1998) A Study of Consumers at a Small Farmers' Market in Maine: Results from a 1995 Survey. Journal of Food Distribution Research, 29, 91-99.

[7] USDA ESMIS ERS U.S. Blueberry Industry table03.xls Average Farm-Gate Value of Blueberry Production, Selected States, 1980-2012.

http://usda.mannlib.cornell.edu/MannUsda/viewDocumentInfo.do?documentID=1 $\underline{765}$

[8] United States Department of Agriculture Statistics Service (2010). http://usda.mannlib.cornell.edu/MannUsda/viewDocumentInfo.do?documentID=1 $\underline{765}$

[9] Druice, J. and Percival, D. (2003) Trends in Lowbush Blueberry Cultivar Development. Journal of the American Pomological Society, 57, 63-69.

[10] Williams, C., Dodd, G., Lamport, D., Spencer, J. and Butler, L. (2017) Effects of Anthocyanin-Rich Blueberries on Cognitive Function in Healthy Younger and Older Adults. Innovation in Aging, 1, 1362. https://doi.org/10.1093/geroni/igx004.5009

[11] Strik, B. (2006) Blueberry Production and Research Trends in North America. Acta Horticulturae, 715, 173-183. https://doi.org/10.17660/ActaHortic.2006.715.25

[12] Ballington, J.R. (1990) Germplasm Resources Available to Meet Future Needs for Blueberry Cultivar Improvement. Fruit Varieties Journal, 44, 54-62.

[13] NeSmith, D.S. (2006) Performance of Old and New Rabbiteye Blueberry Cultivars from the University of Georgia Breeding Program. Acta Horticulturae, 715, 137 139.

[14] Davies, F.S. (1986) Flower Position, Growth Regulators, and Fruit Set of Rabbiteye Blueberries. Journal of the American Pomological Society, 111, 338-341.

[15] Patel, N. and George, J.P. (1997) Progress with Breeding Blueberries in New Zealand. Acta Horticulturae, 466, 149-155. https://doi.org/10.17660/ActaHortic.1997.446.21

[16] Ehlenfeldt, M.K., Ogan, E. and Rowland, L. (2006) Evaluation of Midwinter Cold Hardiness among 25 Rabbiteye Blueberry Cultivars. HortScience, 41, 579-581.

[17] Spiers, J.M. (1978) Effect of Stage of Bud Development on Cold Injury in Rabbiteye Blueberry. Journal of the American Pomological Society, 103, 452-455.

[18] NeSmith, D.S. and Draper, A.D. (2004) Rabbiteye Blueberry Plant Named “Alapaha". U.S. Plant Patent Publication 64,863.

[19] Eck, P. (1988) Blueberry Science. Rutgers University Press, Brunswick, NJ.

[20] Austin, M.E. (1994) Rabbiteye Blueberries. AgScience, Inc., Auburndale, FL.

[21] Van Dalfsen, K.B. and Gaye, M.M. (1999) Yield from Hand and Mechanical Harvesting of Highbush Blueberries in British Columbia. Applied Engineering in Agriculture, 15, 393-398. https://doi.org/10.13031/2013.5794 
[22] Saftner, R., Polashock, J., Ehlenfeldt, M. and Vinyard, B. (2008) Instrumental and Sensory Quality Characteristics of Blueberry Fruit from Twelve Cultivars. Postharvest Biology and Technology, 49, 19-26. https://doi.org/10.1016/j.postharvbio.2008.01.008

[23] Vicinte, A.R., Ortugno, C., Rosli, H., Powell, A.L.T., Grieve, L.C. and Labavitch, J.M. (2007) Temporal Sequence of Cell Wall Disassembly Events in Developing Fruits. 2. Analysis of Blueberry (Vaccinium species). Journal Agricultural and Food Chemistry, 55, 4125-4130. https://doi.org/10.1021/jf063548j

[24] Lyon, P., Collie, V., Kvarnbrink, E. and Colloquium, A. (2009) Shopping at the Farmers' Market: Consumers and Their Perspectives. Journal of Foodservice, 20, 21-30. https://doi.org/10.1111/j.1748-0159.2008.00119.x

[25] Marshall, D.A., Spiers, J.M. and Stringer, S.J. (2008) Blueberry Splitting Tendencies as Predicted by Fruit Firmness. HortScience, 43, 567-570.

[26] Sousa, M.B., Curado, T., Lavadinho, C. and Moldao-Martins, M. (2004) A Survey of Quality Factors in Highbush and Rabbiteye Blueberry Cultivars in Portugal. Acta Horticulturae, 715, 567-572.

[27] Silva, J.L., Marroquin, E., Matta, F.B., Gatner Jr., J.O. and. Stojanovic, J. (2005) Physiochemical, Carbohydrate and Sensory Characteristics of Highbush and Rabbiteye Blueberry Cultivars. Journal of Science of Food and Agriculture, 85, 1815-1821. https://doi.org/10.1002/jsfa.2083

[28] Parra, R., Lifante, Z.D. and Valdes, B. (2007) Fruit Size and Picking Scar Size in Some Blueberry Commercial Cultivars and Hybrid Plants Grown in SW Spain. International Journal of Food Science and Technology, 42, 880-886. https://doi.org/10.1111/j.1365-2621.2006.01299.x

[29] Dozier Jr., W.A., Caylor, A.W., Himelrick, D.G., Powell, A.A. and Akridge, J.R. (1991) Rabbiteye Blueberry Cultivar Performance. Fruit Varieties Journal, 45, 128-134.

[30] Himelrick, D.G., Powell, A.A. and Dozier, W.A. (1995) Commercial Blueberry Production Guide for Alabama. ANR-904.

[31] NeSmith, D.S. (2009) Blueberry Cultivar Development at the University of Georgia. Acta Horticulturae, 810, 79-85. https://doi.org/10.17660/ActaHortic.2009.810.6

[32] Vinson, E.L., Woods, F.M., Kimbel, J.M., Perkins-Veazie, P., Davis, A. and Kessler, J.R. (2010) Use of External Indicators to Predict Maturity of Mini-Watermelon Fruit. HortScience, 45, 1034-1037.

[33] McGuire, R.G. (1992) Reporting of Objective Color Measurements. HortScience, 27, 1254-1255.

[34] Voss, D.H. and Hale, W.N. (1998) A Comparison of Three Editions of the Royal Horticultural Society Colour Chart. HortScience, 33, 13-17.

[35] SAS Institute Inc. (1988) SAS/STAT User's Guide. Release 6.2 Edition, SAS Institute Inc., Cary, NC, 1028 p.

[36] Itle, R.A. and NeSmith, D.S. (2017) Evaluation of Fruit Quality Traits in Southern Highbush and Rabbiteye Blueberries. Acta Horticulturae, 1180, 393-400. https://doi.org/10.17660/ActaHortic.2017.1180.54

[37] Gilbert, J.L., Olmstead, J.W., Colquhoun, T.A., Levin, L.A., Clark, D.G. and Moskowitz, H.R. (2014) Consumerassisted Selection of Blueberry Fruit Quality Attributes. HortScience, 49, 864-873. 